\section{A Child with Lipemic Sample: Berardinelli-Seip Congenital Lipodystrophy}

Sir,

Congenital generalised lipodystrophy is a very rare disorder characterised by lack of adipose tissues and dyslipidemia, especially increased serum triglycerides. Berardinelli-Seip congenital lipodystrophy (BSCL) was first described in 1954 in Brazil. BSCL is an autosomal recessive disease characterised by lipodystrophy and deregulation of glucose and lipid metabolism. ${ }^{1}$ Clinically, patients present with marked atrophy of adipose tissue, acromegaly, acanthosis nigricans, attention deficit hyperactivity and developmental learning problems. All examples present with hypertriglyceridemia. ${ }^{2}$ Leptin alternative therapy can improve condition of $\mathrm{BSCL}$ symptoms. ${ }^{3}$

A 2-month $X Y$ male child was identified with highly chylous serum sample, Parents were contacted to repeat sample and it was again highly lipemic. Afterwards, parents brought the child to Endocrine Clinic, Armed Forces Institute of Pathology (AFIP). On detailed history, the baby was admitted in Military Hospital, Rawalpindi. Patient was admitted with the complaints of recurrent respiratory tract infection, low grade fever off and on and failure to gain weight. He was born to consanguineous parents and two siblings died with same complaints at the age of 1 month and 7th day after birth, respectively. The present baby was born at 38 weeks of gestation with caesarean section in Combined Military Hospital $(\mathrm{CMH})$, Lahore. On general examination, the child showed triangular face with lack of adipose tissue, reduced muscular bulk on buttocks, arms and chest, large chin, protruded tongue and prominent supraorbital ridges, prominent umbilicus and acanthosis nigricans. Respiratory rate was 16 breaths/minute and temperature, $99^{\circ} \mathrm{F}$. On systemic examination, there was hepatomegaly and protruded soft abdomen with normal bowel sounds. Biochemical profile showed deranged lipid profile and liver function tests (LFTs) (Table I).

17-hydroxyprogesterone (17-OHP) was within normal range $(0.8-60 \mathrm{nmol} / \mathrm{L})$, excluding the possibility of congenital adrenal hyperplasia. Testicular scan showed hydrocele. Serum leptin levels were lower normal 0.25
Table I: Routine biochemical profile.

\begin{tabular}{l|c|c}
\hline Serum test & Result & Reference range \\
\hline Triglycerides & $20.4 \mathrm{mmol} / \mathrm{L}$ & $2.3-5.6 \mathrm{mmol} / \mathrm{L}$ \\
LDL-cholesterol & $6.0 \mathrm{mmol} / \mathrm{L}$ & $<2.59 \mathrm{mmol} / \mathrm{L}$ \\
Total cholesterol & $2.14 \mathrm{mmol} / \mathrm{L}$ & $<5.2 \mathrm{mmol} / \mathrm{L}$ \\
Serum alanine aminotransferase (ALT) & $138 \mathrm{IU} / \mathrm{L}$ & Upto $42 \mathrm{IU} / \mathrm{L}$ \\
Alkaline phosphatase (ALP) & $1258 \mathrm{IU} / \mathrm{L}$ & $54-500 \mathrm{IU} / \mathrm{L}$ \\
Serum lactate & $2.91 \mathrm{mmol} / \mathrm{L}$ & $0.5-2.2 \mathrm{mmol} / \mathrm{L}$ \\
Blood glucose & $4.5 \mathrm{mmol} / \mathrm{L}$ & $3.3-11 \mathrm{mmol} / \mathrm{L}$ \\
\hline
\end{tabular}

$\mathrm{ng} / \mathrm{ml}(0.2-13.4 \mathrm{ng} / \mathrm{ml})$. Echocardiography was normal while bone scan showed bone age of 2 years with 2 months chronological age. Liver biopsy report showed hepatocyte swelling and vacuolisation consistent with fatty liver. The anabolic processes cause acromegaloid characteristics, because of insulin-like growth factor 1 (IGF 1) hypersecretion; and the hepatomegaly was probably due to fatty infiltration. Disease progression occurs with liver commonly developing non-alcoholic steatohepatitis and ultimately liver cirrhosis. A pediatrician counselled and advised parents to maintain strict diet for life. Diet with low fats, and low carbohydrates with high amount of soluble fibers was advised. Physician advised follow-up after 6 months and also suggested leptin therapy to be started in later stage of life.

\section{REFERENCES}

1. Ferraria N, Pedrosa C, Amaral D, Lopes L. Berardinelli-Seip syndrome: Highlight of treatment challenge. BMJ Case Rep 2013; 2013:bcr2012007734.

2. Magré J, Delépine $M$, Khallouf $E$, Gedde-Dahl Jr T, Van Maldergem L, Sobel E, et al. Identification of the gene altered in Berardinelli-Seip congenital lipodystrophy on chromosome 11q13. Nat Genet 2001; 28:365.

3. Beltrand J, Beregszaszi M, Chevenne D, Sebag G, De Kerdanet M, Huet $\mathrm{F}$, et al. Metabolic correction induced by leptin replacement treatment in young children with BerardinelliSeip congenital lipoatrophy. Pediatrics 2007; 120:e291-6.

Qurat-ul-Ain, Waqas Sheikh and Noreen Shahzad

Department of Chemical Pathology, Armed Forces Institute of Pathology, Rawalpindi, Pakistan

Correspondence to: Dr: Qurat-ul-Ain, Department of Chemical Pathology, Armed Forces Institute of Pathology, Rawalpindi,

Pakistan

E-mail: draaneiseera@gmail.com

Received: December 26, 2018; Revised: May 18, 2019;

Accepted: May 29, 2019

$$
\text { …두.... }
$$

